\title{
The Removal of COD and Color from Textile Industry by Chlorine Hypochlorite
}

\author{
Mohamadreza Massoudinejad $^{1}$, Mansour Ghaderpoori ${ }^{2 *}$ and Mansour Rezazadeh \\ Azari $^{3}$ \\ ${ }^{1}$ Professors, Department of Environmental Health, Faculty of Health, Shahid \\ Behesht University of Medical Sciences, and member of Safety Promotion \& \\ Injury Prevention Research Centre. Tehran, Iran \\ ${ }^{2}$ Ph.D Candidate, Faculty of Health, Shahid Beheshti University of Medical \\ Sciences, Tehran, Iran \\ ${ }^{3}$ Professor, Department of Occupational Health, Faculty of Health, Shahid \\ Beheshti University of Medical Sciences, and member of Safety Promotion \& \\ Injury Prevention Research Centre. Tehran, Iran \\ *mghaderpoori@sbmu.ac \\ Tel: 98914-185-4098 \\ Fax No: 9821- 22432037
}

\begin{abstract}
Industrial wastewaters are played one of the most important roles in environmental pollutions, but discharge these wastewater to environment has always with irreparable damages. The aim of this study was to explore the removal efficiency of COD and color of polyacrylic Textile Industry by Calcium hypochlorite. In this study, this parameter was measured including total Dissolved Total Solids, Turbidity, and $\mathrm{pH}$. Red and blue color product the maximum rate of color. The removal efficiency of COD was about 96 to 98 per cent and for Turbidity were 72 to 71 per cent. Produced Pollution of imported fibers from Belarus, Spain and Japan is 4.47, 3.07 and 6.33 times lower than native fibers. The method of oxidation with chlorine as the easiest, cheapest and most efficient way of preliminary wastewater treatment plant was used in the textile industry polyacrylic. With this technique within COD decrease, the possibility of wastewater treatment with biological treatment in the final stage is provided.
\end{abstract}

Key Word: Wastewater Treatment, Textile Industry, COD, Chlorine Hypochlorite, Color

\section{Introduction}

The Existence of industries in communities are causing growth and development economical- community but if failure to remark environmental issues and lack of control pollutions result from industrial activates, it will be irreparable effects on the environment. Industrial wastewaters are played one of the most important roles in environmental pollutions, but discharge these wastewater to environment has always with irreparable damages. Today, for the treatment of these pollutants and its control, various methods have been developed. Textile industrials are among industrials that are highly contaminated effluent and need special consideration in their treatment. Table 1 shows the power and intensity of such wastes [1]. To evaluate the quality and quantity production of textile effluents is needed that each stage of the production is well-known to cause pollution of any particular part. Textile industry are includes the steps Spinning, weaving,

* Corresponding Author 
Dyeing. The Fibers are used classified into three general categories: 1. natural 2. Mineral 3. Synthetic fibers. Important steps in produce string and clothe are used in textile industry following the Scouring step the action is required for industries that are used raw material consumption to wash. The effluent results from washing the raw materials is the most polluted wastewater produced in these industries, and it is the largest waste forms. The Bleaching stage is carried out before dyeing and printing stages. The next step is Mercerization. In this process the Mercerizer machine in Dyeing and Finishing Hall only have done on cellulosic fibers by $\mathrm{NaOH}$ and the produced effluent is alkaline. In dyeing because of the use of different colors with a diverse and complex chemical compounds have special properties and for each industry, there is needed special design for wastewater treatment. Addition to chemical composition, color, heavy metals such as chromium and lead too adds to the problem of treatment. As for set processes used in various production processes in the textile industry can divide produced pollutants to the following compositions. These compounds include suspended solids, $\mathrm{BOD}_{5}$, which is more related to natural textile fibers, nitrogen and phosphorus compounds that are used in the part of detergents, acids, alkali and heavy metals that are used in the part of painting. Also, the high temperature is of the other problems associated with this industrial wastewater [2]. Polyacrylic textile industrial wastewaters usually are containing high COD and low BOD levels. So far, various methods of physical, chemical and biological processes have been used to remove paint from these industries. Physical methods are decreased slightly because the produced colors in these industries are colloidal nature and effectively removed have not by these processes. Chemical methods such as the use of alum, commonly successfully used to blend the colors are insoluble. Adsorption method using activated carbon is applied as a way to remove the paint. This method is not economical from the point of regenerated activated carbon, inefficiencies to remove all paints and high cost. Most of the colors used in dyeing industries are non-biological decomposition, because of create strong complexes. Based on studies on the biological degradation of textile dyes, color removal rate was 15 percent after the period of 30 days [3].

The biggest problems these effluents are include remaining dyes, high temperature, low $\mathrm{pH}$, non-biodegradation resistant chemical that usually completed through various chemical treatments on fabrics are imported [4]. Because of the high consumption of water and exist waste industries including dye materials, catalysts, salts, acids, alkalis and heavy metals, textile effluents are classified between the most polluted industrial effluents $[5,6]$. With respect to current standards for effluent discharge into acceptor waters and regarding the problems of conventional methods exists for color separation, it seems necessary Select the proper a method to remove paint that has high performance, and have few problems than other methods. In addition, so far methods of various physical, chemical and biological have been used for wastewater color removal from various textile but each of these methods because of unknown reasons, the application did not find the necessary industry. In recent years, the cost of textile wastewater treatment has increased rapidly. So searching for more economical treatment is required $[7,8]$. The aim of this study was to explore the removal efficiency of COD and color of polyacrylic Textile Industry by Calcium hypochlorite.

Table 1. Classification of Textile Wastewater

\begin{tabular}{cccc}
\hline Type & $\begin{array}{c}\text { BOD } \\
(\mathbf{m g} / \mathbf{l})\end{array}$ & $\begin{array}{c}\text { COD } \\
(\mathbf{m g} / \mathbf{l})\end{array}$ & $\begin{array}{c}\text { Temperature } \\
\left({ }^{\circ} \mathrm{C}\right)\end{array}$ \\
\hline Strong & 500 & 1500 & 28 \\
Average & 270 & 970 & 28 \\
Week & 100 & 460 & 31 \\
\hline
\end{tabular}




\section{Materials and Methods}

\subsection{Treatment Diagram}

Textile industry wastewater treatment steps are studied in Figure 1. Average production of wastewater is $16 \mathrm{~m}^{3} /$ day from dyeing unit. In this process, the wastewater enters stabilization pond. Stabilization basins with volume equal $8 \mathrm{~m}^{3} /$ day to number 2 are filled intermittently. In these basins, temperature reduces from $65^{\circ}$ to $20^{\circ}$. While reducing the temperature, suitable the color type and the powder of Calcium hypochlorite, is doing the removal of Color and COD. Then, the lime water is balanced wastewater $\mathrm{pH}$ from stabilized basin. Residual chlorine in the stabilized basin is removed [1]. To remove of final material and residual compounds, output wastewater by a pump with flow rate $0.68 \mathrm{~m}^{3} / \mathrm{h}$ injected to the aeration basin in activated sludge.

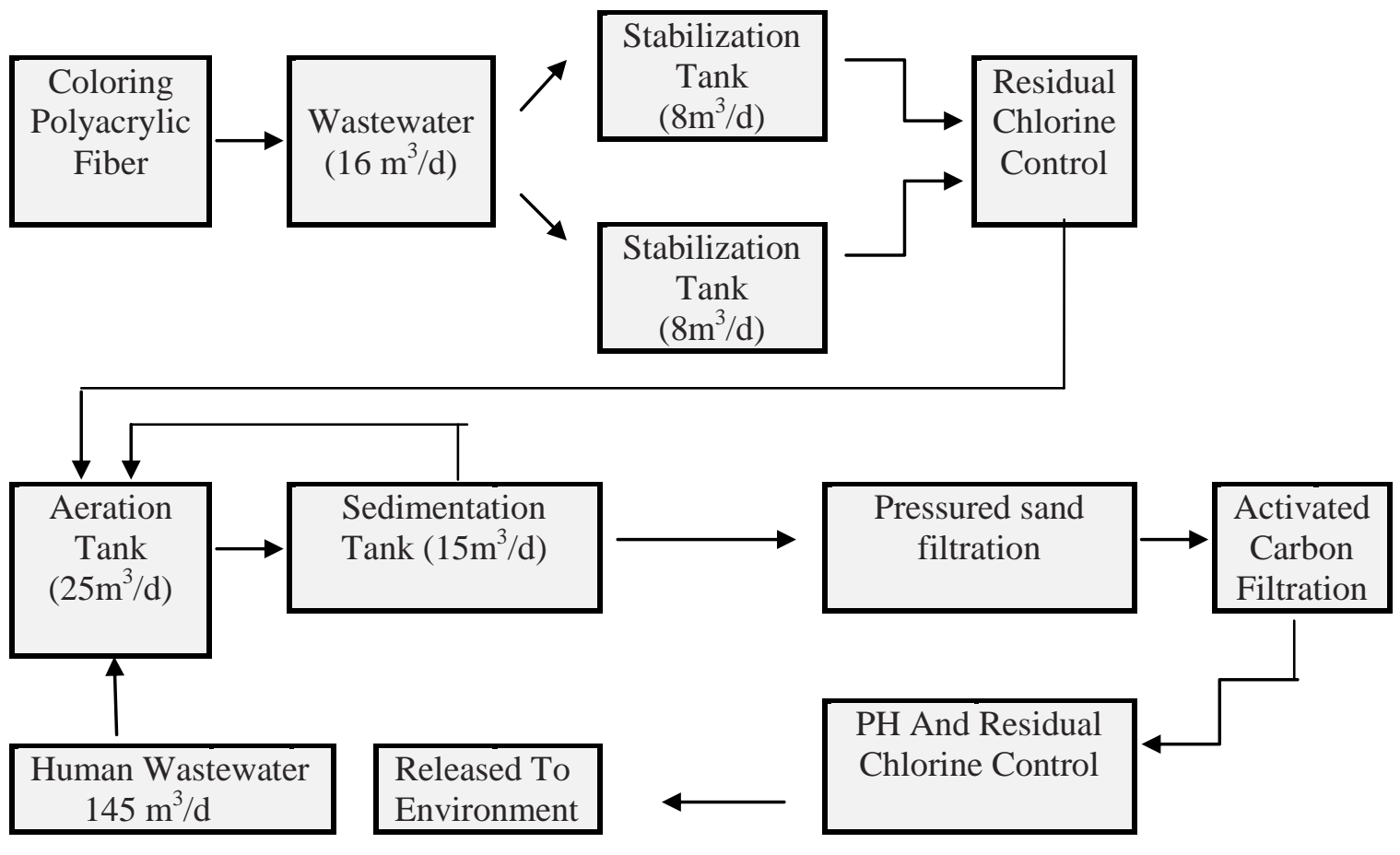

Figure 1. Wastewater Treatment Steps in Textile Industry

\subsection{The Used Materials}

In this study, this parameter was measured including total dissolved (TDS) total solids (TS), Turbidity, Color (wavelength range from 400 to $700 \mathrm{~nm}$ ) and $\mathrm{pH}$. All the tests carried out according to Standard Methods for Examine Water and Wastewater [9].

\subsection{Concentration of color and COD}

The following equations were used to evaluate the efficiency of calcium hypochlorite oxidation and removal of COD and color from effluent:

- Calculated the COD removal efficiency

$$
\mathrm{COD} \text { removal efficiency, } \%=\frac{\text { Initial } \mathrm{COD} ? \text { Final } \mathrm{COD}}{\text { Initial } \mathrm{COD}} \times 100
$$


- Estimated the color removal efficiency

$$
\text { Color removal efficiency, } \%=\frac{\text { Initial Color } ? \text { Final Color }}{\text { Initial Color }} \times 100
$$

\section{Result and Discussion}

Various methods of physical, chemical and biological wastewater treatment for the removal of dyes from textile industries have been used. Biological methods often are not able to remove large amounts of color in the effluent because of high levels of COD, temperature increase during the unload of boilers and acidic $\mathrm{pH}$. Therefore, we must use of cost-effective methods for the removal of color and COD significantly [10]. In this study, for determined what contamination was in existing wastewater and what color or colors created the most pollution, the first step was analyzed effluent. The results of this analysis are shown in Table 2. Red and blue color had maximum COD rate compare with other colors. Therefore, this design was based on the worst-case. Red and blue color product the maximum rate of color. So these colors had main role in product of effluent (Table 2). The extent and severity of the pollution of these colors are shown in Table 3.

Table 2. The Ingredients of Used Color in the Textile Industry

\begin{tabular}{|c|c|c|c|c|c|}
\hline $\begin{array}{l}\text { Color } \\
\text { type }\end{array}$ & $\begin{array}{c}\text { Color rate } \\
\left(\mathrm{kg} / \mathrm{m}^{3}\right)\end{array}$ & $\begin{array}{l}\text { Retarder } \\
\text { per liter }\end{array}$ & $\begin{array}{c}\text { Acetic } \\
\text { acid (90 } \\
\%)\end{array}$ & $\underset{\left(\mathrm{kg} / \mathrm{m}^{3}\right)}{\text { Soap }}$ & $\begin{array}{c}\text { Softener } \\
(250 \\
\left.\mathrm{kg} / \mathrm{m}^{3}\right) \\
\end{array}$ \\
\hline Red & 13.3 & 0.3 & 1 liter & remove & 7.4 \\
\hline Blue & 13.3 & 0.3 & 1 liter & remove & 8.2 \\
\hline Olivaceous & 13.3 & 0.3 & 1 liter & 0.3 liter & 0.6 \\
\hline Cream & 13.3 & 0.3 & 1 liter & 0.3 liter & 0.25 \\
\hline Buibar & 13.3 & 0.3 & 1 liter & 0.3 liter & 0.4 \\
\hline Blue-oil & 13.3 & 0.3 & 1 liter & 0.3 liter & 2 \\
\hline
\end{tabular}

Base on performed experiments in the wastewater treatment with coagulants; only show efficiency of about 30 to 40 per cent in removing suspended solid and colloidal particle. Also if combined process of coagulation and activated carbon are used simultaneously, after past 4 hours COD reduce rate was about 45 percent $[11,12]$. The results of the above methods are not able reduce the number of pollutants in effluent to unload receiving water to standard, thus, it would not desirable for polyacrylic textile wastewater treatment. The removal efficiency of COD was about 96 to 98 per cent and for Turbidity were 72 to 71 percent. So the integration of chemical oxidation and biological methods showed more favorable results about decrease of COD and suspended solids. Table 3 shows summarized results of the input and output wastewater plant with treatment by chemical-biological methods.

Table 3. Pollutant Rate from the Most Pollutant used Color in the Polyacrylic Textile Industry

\begin{tabular}{llllll}
\hline color Type & pH & $\begin{array}{l}\text { COD } \\
(\mathrm{mg} / \mathrm{l})\end{array}$ & TS (mg/l) & TSS (mg/l) & TDS (mg/l) \\
\hline Red & 4.3 & 4350 & 4520 & 80 & 4440 \\
Blue & 4.5 & 4600 & 4850 & 65 & 4785 \\
\hline
\end{tabular}

In this study for COD oxidation and decrease of that up to suitable level for biological treatment as pretreatment was used calcium hypochlorite $\left(\mathrm{Ca}(\mathrm{ClO})_{2}\right)$. Calcium hypochlorite reacts with water as follows: 
Calcium Hypochlorite? + Water $\rightarrow$ Hypochlorous Acid + Calcium Hydroxide?

$\mathrm{Ca}(\mathrm{OCl})_{2}+2 \mathrm{H}_{2} \mathrm{O} \rightarrow 2 \mathrm{HOCl}+\mathrm{Ca}(\mathrm{OH})$

Table 4 shows the characteristics of input and output wastewater. To evaluate the effect of Calcium hypochlorite on COD and color was used the different concentrations, which Figure 1 and 2 shows varies the removal of COD and Color

Table 4. Characteristics of Input Wastewater and Output Effluent from Plant

\begin{tabular}{cccc}
\hline Items & $\begin{array}{c}\text { Input effluent } \\
(\mathbf{m g} / \mathbf{l})\end{array}$ & $\begin{array}{c}\text { Output effluent } \\
(\mathbf{m g} / \mathbf{l})\end{array}$ & $\begin{array}{c}\text { Removal efficiency } \\
(\boldsymbol{\%})\end{array}$ \\
\hline COD & $3280-6650$ & $119.5-128$ & $96-98$ \\
TDS & $9300-10700$ & $1600-2100$ & $80-83$ \\
TSS & $75-180$ & 4061 & $47-49$ \\
Turbidity & $200-220$ & $58-62$ & $71-71$ \\
PH & $3.9-6.1$ & $7.1-7.4$ & - \\
BOD $_{5}$ & $280-320$ & $62.1-65.3$ & $78-80$ \\
\hline
\end{tabular}

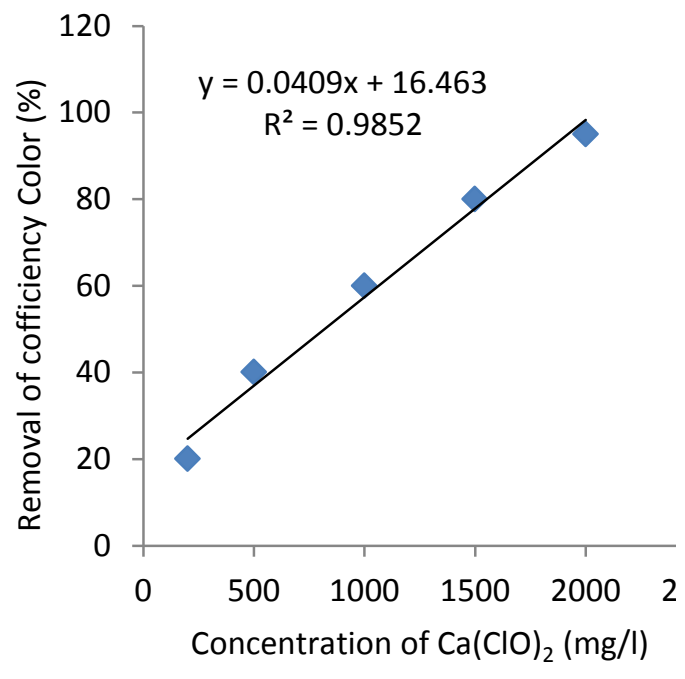

Figure 3. Color Changes with the Addition Calcium Hypochlorite

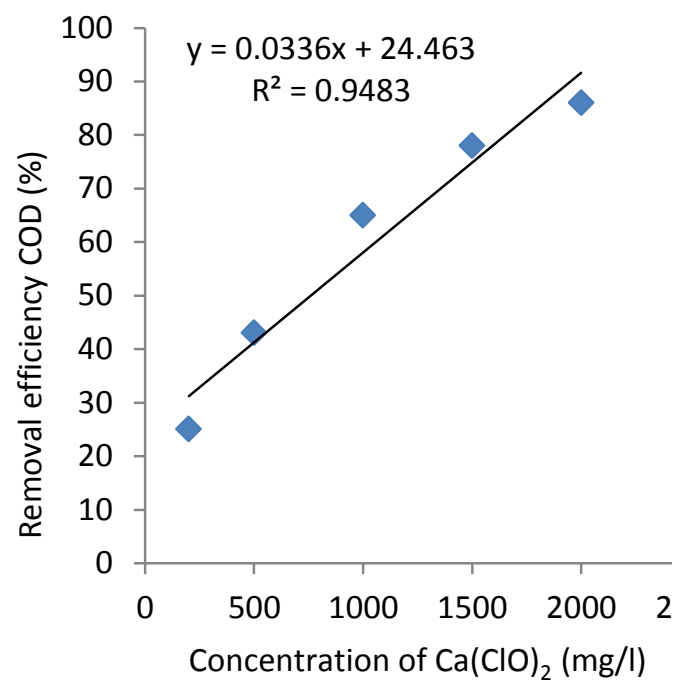

Figure 2. COD Changes with the Addition Calcium Hypochlorite

With use the oxidation process of Calcium Hypochlorite, $1 \mathrm{mg} / \mathrm{l}$ of $\mathrm{Ca}(\mathrm{ClO})_{2}$ with the retention time 10 minutes COD was reduced by 65 per cent. With oxidation with $\mathrm{Ca}$ $(\mathrm{ClO})_{2}$, the color could remove in output effluent up to 95 percent. Base on previous studies which physic-chemical processes were used to remove pollutants from textile industry, can find out the removal rate is not enough for unload effluent standard $[1,13]$. By combining chemical oxidation process with Calcium Hypochlorite before biological treatment process can provide relevant standards (unload standard) [14]. After oxidation with Calcium hypochlorite, the residual chlorine can be removed with sodium thiosulfate (Figure 1). output effluent was unload to aeration tank during the 12 hours with flow rate of $0.68 \mathrm{~m} 3 / \mathrm{d}$ periodically that it was predicted for treatment of sewage treatment (flow rate $145 \mathrm{~m}^{3} / \mathrm{d}$ ). Also to remove residual COD, biological activated sludge process removed in the aeration tank 5 and 35 per cent of COD and color, respectively. To achieve this purpose, two activated carbon column were used in the output path. These columns can meanwhile remove residual colors that remain in the previous units and didn't remove, suspended solids which were produced in aeration tank because of 
biological interaction can remove. The characteristics of the wastewater before and after treatment show in Table 4. In this study, two types of chlorine (import and native) were used which the results shown in Table 5. In the same condition, performs imported Calcium hypochlorite is not comparative with the native (Table 5). The efficiency of imported chlorine with concentration of $1000 \mathrm{mg} / \mathrm{l}$ in COD concentration $3440 \mathrm{mg} / \mathrm{l}$ in compare with native chlorine was about 3.65 times more that this efficiency was significantly. Therefore, it is recommended that import chlorine used because of the poor quality of native chlorine in compare with the imported one and low efficiency in COD remove. One case that examined in this study was the find out of role of fibers in their pollution. The investigations revealed the different fibers are used in the textile industry including the produced fibers from Belarus, Spain and Japan. COD production rates of different fibers have been shown in table 6.native fibers effluents produced $2432 \mathrm{mg} / \mathrm{l}$ COD. So these native fibers were produced the most pollution. Produced Pollution of imported fibers from Belarus, Spain and Japan is 4.47, 3.07 and 6.33 times lower than native fibers. Cause the high-level of pollution in the native fibers could be because of fiber breaking when the constituent of fibers are being in the first round batting. Each fiber has thickness, length, tensile strength and different absorption coefficient that are affected on effluent pollution in the batting stage. In the dyeing process after mixing were immersed with water without salt in a temperature of $65^{\circ} \mathrm{C}$. After addition of acetic acid, softener, retarder (slow drying) is exposed with fibers. Each color according to ask type was being a certain number of effective materials, the used number for each from different colors and the characteristics of the chemical of used color are different[10].

Table 5. The Compare with Native and Import Chlorine in the Removal of COD in the Textile Industry

\begin{tabular}{|c|c|c|c|c|c|}
\hline Sample type & $\begin{array}{c}\text { Early } \\
\text { concentration of } \\
\text { chlorine }(\mathrm{mg} / \mathrm{l})\end{array}$ & $\begin{array}{l}\text { Contact } \\
\text { time } \\
\text { (hour) }\end{array}$ & $\begin{array}{l}\text { Early } \\
\text { COD } \\
(\mathrm{mg} / \mathrm{l}) \\
\end{array}$ & $\begin{array}{c}\text { Residual } \\
\text { COD (mg/l) }\end{array}$ & $\begin{array}{c}\text { Removal } \\
\text { efficiency } \\
(\%)\end{array}$ \\
\hline $\begin{array}{l}\text { Import } \\
\text { chlorine }\end{array}$ & 1000 & 1 & 3440 & 2200 & 36.05 \\
\hline $\begin{array}{l}\text { Import } \\
\text { chlorine }\end{array}$ & 2000 & 1 & 3440 & 2450 & 28.78 \\
\hline $\begin{array}{l}\text { Native } \\
\text { chlorine }\end{array}$ & 1000 & 1 & 3440 & 3100 & 9.88 \\
\hline $\begin{array}{l}\text { Native } \\
\text { chlorine }\end{array}$ & 2000 & 1 & 3440 & 3200 & 6.98 \\
\hline $\begin{array}{l}\text { Import } \\
\text { chlorine }\end{array}$ & 1000 & 1 & 1280 & 736 & 42.5 \\
\hline $\begin{array}{l}\text { Import } \\
\text { chlorine }\end{array}$ & 2000 & 1 & 1280 & 896 & 30 \\
\hline $\begin{array}{l}\text { Native } \\
\text { chlorine }\end{array}$ & 1000 & 1 & 1280 & 992 & 22.5 \\
\hline $\begin{array}{l}\text { Native } \\
\text { chlorine }\end{array}$ & 2000 & 1 & 1280 & 944 & 26.25 \\
\hline
\end{tabular}

As a result, the resistance of native chlorine is lower than import chlorine. During these stages, the fibers converted to tiny particle which eventually led to raise the number of COD in compare with import types. So when using imported fibers will reduce a lower COD level, resulting in, less expensive treatment is needed. The results of parameters are shown in the Table 7. As can be viewed, the COD rate is decreased from $4350 \mathrm{mg} / \mathrm{l}$ to $135.87 \mathrm{mg} / \mathrm{l}$ and according to environmental standards this COD rate can be removed without difficulty by biological treatment [10]. Besides the chemical composition, also the 
existence of heavy metal such as chromium and lead are increased treatment problems [2]. The results showed the concentrations of lead and chromium were equal to $0.5 \mathrm{mg} / \mathrm{l}$ and zero, respectively. Environmental standards for lead, chromium (III) and chromium (VI) in environmental standards are 1,2 and $0.5 \mathrm{mg} / \mathrm{l}$, respectively. To more accurate control in plants after aeration and sedimentation basins, it installed a pressure sand filter and an activated carbon column. Passing the effluent from this stage because that quality effluent close to highest level and output effluent can be unloading to surface waters or absorbed wells.

\section{Conclusion}

The results of this research indicate that Calcium hypochlorite was effective for the removal of Color and COD from textile industries wastewater. Overall, it can be pointed to the following conclusions:

- Red and blue color had maximum COD rate compare with other colors.

- In this study for COD oxidation and decrease of that up to suitable level for biological treatment

- By combining chemical oxidation process with Calcium Hypochlorite before biological treatment process can provide relevant standards (unload standard)

- The efficiency of imported chlorine in compare with native chlorine (Iranian) was about 3.65 times more that this efficiency was significantly.

- Produced Pollution of imported fibers from Belarus, Spain and Japan is 4.47, 3.07 and 6.33 times lower than native fibers

Table 6. The Production Rate of COD According to the Fiber

\begin{tabular}{cc}
\hline Sample type & Produced COD $(\mathbf{m g} / \mathbf{l})$ \\
\hline Output plant & 352 \\
Effluent from native fibers & 2432 \\
Imported fibers from Belarus & 544 \\
Imported fibers from Spain & 800 \\
Imported fibers from Japan & 384 \\
\hline
\end{tabular}

Table 7. Measured Concentrations in Produced Effluent (Before Entering to the Biological Unit)

\begin{tabular}{ccc}
\hline Parameter & Unit & Concentration $(\mathbf{m g} / \mathbf{l})$ \\
\hline Temperature & ${ }^{\circ} \mathrm{C}$ & 19.53 \\
$\mathrm{pH}$ & $\mathrm{mg} / \mathrm{l}$ & 7.72 \\
$\mathrm{BOD} 5$ & $\mathrm{mg} / \mathrm{l}$ & 74.03 \\
$\mathrm{COD}$ & $\mathrm{mg} / \mathrm{l}$ & 135.87 \\
$\mathrm{NH}_{3}$ & $\mathrm{mg} / 1$ & 25.72 \\
$\mathrm{NO}_{3}{ }^{-}$ & $\mathrm{mg} / \mathrm{l}$ & 7.04 \\
$\mathrm{NO}_{2}^{-}$ & $\mathrm{mg} / 1$ & 0.16 \\
$\mathrm{TDS}$ & $\mathrm{mg} / 1$ & 1466.67 \\
$\mathrm{TS}$ & $\mathrm{mg} / 1$ & 36.33 \\
$\mathrm{TP}$ & $\mathrm{mg} / 1$ & 22.31 \\
Lipid & $\mathrm{mg} / 1$ & 13.8 \\
EC & $\mathrm{Mmho} / \mathrm{cm}$ & 2590 \\
Turbidity & $\mathrm{NTU}$ & 29.37 \\
Temperature & ${ }^{\circ} \mathrm{C}$ & 19.53 \\
\hline
\end{tabular}




\section{References}

[1] E. Balanosky, F. Herrera and A. Lopez, "Oxidative degradation of textile wastewater modeling reactor performance", J Water Res., vol. 23, no. 6, (1999) pp. 102-110.

[2] G. Ciardelli, G. Capanelli and A. Borrinom, "Ozone treatment of textile wastewater for reuse", J Water Sci and tech., vol. 44, no. 3, (2001) pp. 64-67

[3] N. M. A. Behnajady, "Kinetic study on photocatalytic of C.J.Acid yellow 23 by ZnO Photocatalyst", ,Modir and R. Hamzavi., vol.133, (2006), pp. 226-232.

[4] J. Eastan and P. Cooper, "Color in dye house effluent", The Alden press, (1995).

[5] M. Amini, M. Arami, A. Akbari and N. M. Mahmoodi, "Preparation of nanofiltration membrane via UV photo - grafting technique for separation of acid dyes at different $\mathrm{pH}$ values", Journal of Color Science and Tecnologhy, no. 2, (2008), pp. 237-247.

[6] A. R. Tehrani-Bagha, N. M. Mahmoodi and M. Arami, "Study of the effective parameters on decolorization of C.I.Reactive Black 5 wastewater by Ozonation", Journal of Color Science and Technology, no. 2, (2008), pp. 67-75.

[7] M. H. Dehghani, "Evaluation of sonochemical reactors efficiency in color removal from textile indusries effluent", research project report to Tehran University of Medical of Science 2006, Tehran, Iran, (2006).

[8] M. Anoosheh, M. T. Samady and M. R. Samarghandi, "Comparing the efficiency Advanced Oxidation Processes $\mathrm{TiO}_{2} / \mathrm{UV}$ and ozonation in the removal of Acidic Color Black $10 \mathrm{~B}$ and Acid Cyanin 5R", $12^{\text {th }}$ Conference of National Environmental Health: Shahid Beheshti University of Medical of Science. Tehran. Iran, (2008).

[9] A. D. Eaton, L. S. Clesceri and E. W. Rice, "Standard Methods for the Examination of Water and Wastewater", $21^{\text {th }}$ ed. Washington DC: American Water Works Association, (2005).

[10] Y. Kaslech and M. Perkowski, "Decoloration of real textile wastewater with advanced oxidation processes", Fibers \& Textiles in Eastern Europe, vol. 4, no. 4, (2003), pp. 81-86.

[11] A. Yasar, N. Ahmad, M. N. Chaudhry, M. S. U. Rehman and A. A. A. Khan, "Ozone for Color and COD Removal of Raw and Anaerobically Biotreated Combined Industrial Wastewater", Polish J. of Environ. Stud., vol. 16, (2007), pp. 289-294.

[12] G. R. P. Malpass, D. W. Miwa, D. A. Mortari, S. A. S. Machado and A. J. Motheo, "Decolorisation of real textile waste using electrochemical techniques: Effect of the chloride concentration", Water Research., vol. 41, (2007), pp. 2969-2977.

[13] C. Namboodri, W. Perkins and W. Walsh, "Decolorizing dyes with chlorine and ozone, Part 11", Dyestuff reporter., vol. 83, no. 4, (1994), pp. 17-26.

[14] A. K. M. A. Quader, "Treatment of textilewastewater with chlorine: An effective method", Chemical Engineering Research Bulletin., vol. 14, no. 1, (2010), pp. 59-63. 